\title{
AVIDIN EXPRESSION DOES NOT INCREASE SPEED OF KILL OF SPODOPTERA LITURA BY BACULOVIRUS
}

\author{
L.N. GATEHOUSE ${ }^{1}$, N.P. MARKWICK ${ }^{2}$, J. POULTON ${ }^{2}$ and \\ J.T. CHRISTELLER ${ }^{1}$
}

\author{
${ }^{1}$ HortResearch, Private Bag 11030, Palmerston North \\ ${ }^{2}$ HortResearch, Mount Albert Research Centre, Private Bag 92169, Auckland
}

Corresponding author: lgatehouse@hortresearch.co.nz

\begin{abstract}
A disarmed (polh-minus) Autographa californica nuclear polyhedrosis virus-based baculovirus expressing green fluorescent protein (GFP) on the strong late promotor p10 was constructed. A second virus was made which also expressed the biotin-binding protein, avidin, from the strong late promotor polh. Both viruses caused strong fluorescence in Spodoptera frugiperda cells in insect cell culture. Seven-day-old larvae of Spodoptera litura were inoculated by microinjection with GFP virus, GFP+avidin virus or tissue culture medium (control). Mortality, growth rate and the development of green fluorescence were followed and after death the larvae were analysed for GFP and avidin content. All virus-injected larvae developed strong fluorescence. However, no significant differences in growth or mortality were seen between the larvae injected with virus expressing and not expressing avidin. Both GFP and avidin accumulated to high levels in the larvae. The expression of avidin did not change the level of expression of GFP.

Keywords: avidin, baculovirus, Spodoptera litura.
\end{abstract}

\section{INTRODUCTION}

Baculoviruses are restricted to arthropods, almost exclusively to insects, and their host range is limited to the Order from which they were isolated (Cory 2000). Due to their non-infectivity to vertebrates they are very safe to work with in the laboratory. Moscardi (1999) assessed the application of baculoviruses as potential insect control agents for lepidopteran pests. It was stated that their role in insect pest control has been limited for several reasons including their narrow host range and slow killing speed compared to chemical insecticides. Moscardi (1999) also reviewed research aimed at broadening the host range and reducing killing times of several baculoviruses. Such attempts have included formulation additives, and more recently, engineering viruses to express insecticidal genes. These engineered viruses often achieve high levels of heterologous gene expression and most eukaryotic post-translational processing is correctly carried out. Examples of such engineering of baculoviruses include expressing virulence-associated proteins such as enhancin (Hayakawa et al. 2000), insect specific toxins such as arthropod venoms (Maeda 1994) and Bacillus thuringiensis toxins (Martens et al. 1990), insect hormones (Miller 1995) and the deletion of the egt (ecdystroid UDPglucosyltransferase) gene (Treacy et al.1997).

AcMNPV (Autographa californica multicapsid nuclear polyhedrosis virus) is the type species for the Baculoviridae and has been studied in detail at the molecular level (Miller 1997). It has a circular double-stranded genome of about $130 \mathrm{~kb}$ and has been completely sequenced (Ayres et al. 1994). It has a relatively wide host range compared to other baculoviruses (Cory et al. 1997), primarily infecting noctuid larvae, including Spodoptera litura F. (Lepidoptera: Noctuidae). S. litura, the cotton leaf worm or tropical armyworm, is a pest in many countries, affecting cotton, rice, sunflowers, brassicas, peanuts and tobacco (Hill 1975; Li \& Rahamann 1997; Ayyanna et al. 1978; Zaz \& Kushwaha 1984; 
Sahayaraj \& Paulraj 1998). Resistance to both Bacillus thuringiensis-based and chemical insecticides is becoming problematical for this species (Armes et al. 1997) and novel methods of control will be important in the future.

The aim of this study was to enhance the infectivity and/or reduce the time taken by AcMNPV to kill its semi-permissive host, S. litura. To do this AcMNPV was engineered to express two proteins: green fluorescent protein (used as a marker of viral gene expression) and the insecticidal protein avidin. Avidin, a biotin-binding protein, is insecticidal when added to artificial diets and fed to a wide range of insects (Bruins et al. 1991; Morgan et al. 1993; Markwick et al. 2001). Further, when avidin is expressed in tobacco it is insecticidal to S. litura and Helicoverpa armigera Walker (Lepidoptera: Noctuidae) (Burgess et al. 2002) and in maize reduces growth and survival of a number of storage pests (Kramer et al. 2000). It is possible that avidin carried into the insect's body by a virus may also have an insecticidal effect by interfering with biotin metabolism. An additive or synergistic reaction between the virus and the protein would increase the virulence of the virus.

\section{MATERIALS AND METHODS}

\section{Baculovirus constructs}

The baculoviruses were made using the FastBac system (Invitrogen, CA, USA) which produces disarmed (polyhedrin-minus) viruses. These have a very low infectivity by the normal oral route but efficiently infect by microinjection into the haemolymph of susceptible hosts. The particular FastBac plasmid used, pFastBac DUAL, allows the expression of two heterologous genes, one on the strong late polh (polyhedrin) promotor and the other on the strong late p10 promotor.

The green fluorescent protein (GFP) gene GFP5 (Prasher et al. 1992; Chalfie et al.1994) was cloned into the Xho I to Kpn I sites of pFastBac DUAL where it is under control of the strong late p10 promotor. A second construct was also made by cloning the avidin gene, including its N-terminal propeptide (Gope et al. 1987), into the BamH I to Hind III sites of the above construct where it is under the control of the strong late polh promotor. The two constructs were mobilised into bacmids in E. coli DH10Bac (Invitrogen), the resulting baculovirus DNA isolated and transfected into Spodoptera frugiperda (JE Smith) (Lepidoptera: Noctuidae) Sf9 cells where expression of GFP and GFP and avidin occurred and budded virus was produced.

To ensure that the same amount of each virus was used, virus was titred by serial dilution and infection of Sf9 cells in microtitre plates. Each dilution occupied one column (8 wells) and was scored for green fluorescence. The titres of the GFP virus and the GFP/avidin virus were within two-fold of one another.

\section{Insect bioassays}

Seven-day-old $S$. litura larvae were obtained from a laboratory colony at HortResearch where they were raised on lima bean diet (McManus \& Burgess 1995) in communal boxes, at $23 \pm 1^{\circ} \mathrm{C}$. The larvae were weighed individually prior to injection.

The microinjection solution consisted of $50 \%$ (by volume) penicillin/streptomycin and $50 \%$ treatment solution. Twenty larvae per treatment were each injected with $1 \mu \mathrm{l}$ of microinjection solution. The site of injection was between the first abdominal segments directly behind the black marking. The three treatments were (i) insect tissue culture fluid (TCF) (Control), (ii) virus expressing green fluorescent protein (GFP) and (iii) virus expressing GFP and avidin.

After injection, larvae were placed in individual, ventilated, $60 \mathrm{ml}$ sampler tumblers (Galantai (Plastics) Group Ltd, Auckland, NZ) containing $1 \mathrm{ml}$ of lima bean diet and maintained at $23 \pm 1^{\circ} \mathrm{C}$. Larval mortality was recorded daily and live larvae that had not begun to pupate were weighed 7 days after microinjection. The experiment was carried out on three occasions. Data from the replicates were analysed separately to produce means and statistical analyses were carried out as described below.

Larvae were also examined under a fluorescence microscope (Leica MZ FLIII Fluorescence stereomicroscope) after 1, 2, 3, 5 and 7 days to determine whether GFP fluorescence was visible and to record the timing and progress of GFP fluorescence by 
photograph. The filter set was the Leica GFP2 filter set (excitations 480/40 nm, barrier filter $510 \mathrm{~nm}$ ) and images were collected using a Nikon Coolpix 995 camera system (low light Roper Scientific CoolSnap camera).

GFP and avidin were analysed by ELISA. Larvae were ground directly into $6 \mu \mathrm{l}$ coating buffer/mg larva ( $15 \mathrm{mM}$ sodium carbonate, $30 \mathrm{mM}$ sodium hydrogen carbonate, $\mathrm{pH}$ 9.6) and centrifuged. Diluted aliquots of the supernatant were added to microtitre plates (Nunc MaxiSorb). Protein levels were detected using rabbit polyclonal antibodies (anti-GFP: Clontech; anti-avidin: Sigma) and goat anti-rabbit IgG-alkaline phosphatase and standardised using authentic protein (GFP: Clontech; avidin: Sigma). Protein was determined in the extracts using the BCA Protein Kit (Pierce Co. Ltd.)

\section{Statistical analysis}

Survival curves and minimum longevity times were estimated for larvae in each treatment using the Kaplan-Meier method for censored data (an s-plus technique, Statistical Sciences Inc. 1991). To test whether there was a difference between two or more survival curves, the G-rho family of tests of Harrington \& Fleming (1982) and Fleming \& Harrington (1984) was used.

To compare percent larval mortality across treatments, the data were transformed by angular transformation (arcsin $\div \mathrm{x}$ ) and analysed by analysis of variance (ANOVA), using Genstat 5. Release 3.2 for Sun/Unix, and hence Tukey LSD values $(\mathrm{P}<0.05)$ apply to transformed values only. Larval weight data were not skewed and transformation before ANOVA was therefore unnecessary.

\section{Baculovirus constructs}

\section{RESULTS}

Both virus constructs when transfected into Sf9 insect cells showed strong green fluorescence indicating the production of GFP (data not shown). Budded virus from both constructs when injected into $S$. litura larvae caused the development of strong green fluorescence indicating the production of GFP (data not shown).

Fluorescence was first observed in S. litura larvae $48 \mathrm{~h}$ after injection with polh AcMNPV expressing either GFP alone or GFP and avidin. At this stage, pin-pricks of fluorescence were observed at the base of hairs and near the injection scar. By $72 \mathrm{~h}$, patches of fluorescence were visible over most of the larval body and within a further $24 \mathrm{~h}$ larvae were totally aglow.

\section{Insect bioassays}

Figure 1 shows survival curves for larvae injected with insect-tissue culture medium (TCF) and polh-minus AcMNPV expressing either GFP alone or GFP and avidin. There were no significant differences in the estimated survival curves or minimum longevity times $(\mathrm{P}=0.275, \mathrm{LSD}=1.27)$ between larvae injected with AcMNPV expressing GFP alone (9.3 days) and those injected with AcMNPV expressing both GFP and avidin (8.8 days). However, survival curves and minimum longevity times were significantly different $(\mathrm{P}<0.001, \mathrm{LSD}=2.10)$ when the two virus treatments were compared to the controls (20.4 days). From 6-10 days after injection there was a trend towards higher proportional mortality in larvae injected with AcMNPV expressing avidin but this was not statistically significant.

Larval growth rate of $S$. litura larvae from neonate to early $5^{\text {th }}$ instar is exponential and the log of larval weights gives a straight line. Therefore larval growth rate was calculated as $\log _{\mathrm{e}}$ final weight $-\log _{\mathrm{e}}$ initial weight. Larval growth rates for each treatment and each replicate are shown in Figure 2. Injection of 7-day-old S. litura larvae with either of the AcMNPV treatments significantly reduced their growth rate over the next 7 days (AcMNPV + GFP: 1.21, AcMNPV + GFP + avidin: 1.38) compared to control larvae (2.71) injected with insect tissue culture fluid ( $<<0.001, \mathrm{LSD}=0.73)$. However, there was no significant difference in growth rate between larvae injected with AcMNPV + GFP and AcMNPV + GFP + avidin $(\mathrm{P}=0.496)$. 


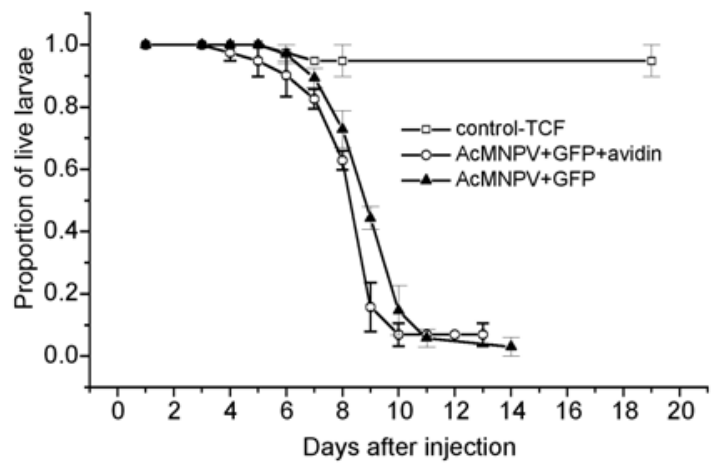

FIGURE 1: Survival of seven-day-old Spodoptera litura larvae after injection with insect tissue culture fluid (TCF) or polh-minus AcMNPV expressing either GFP alone or GFP and avidin. Error bars are SEM.

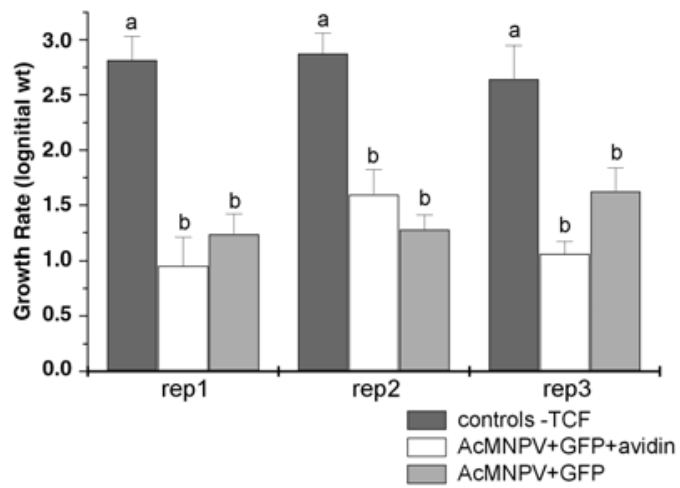

FIGURE 2: Growth rates of Spodoptera litura larvae after injection at 7 days with insect tissue culture fluid (TCF) or polh-minus AcMNPV expressing either GFP alone or GFP and avidin. Error bars are SEM.

\section{Avidin/GFP analysis of dead larvae}

High levels of GFP, as indicated by the intense fluorescence, were expressed in larvae injected with AcMNPV expressing GFP alone (1.09 $\pm 0.08 \%$ total protein) and in combination with avidin (1.53 $\pm 0.21 \%$ total protein). These were not significantly different $(\mathrm{P}=0.14)$ indicating that avidin expression by the virus did not affect the production of GFP. This was despite the fact that the level of avidin $(2.34 \pm 0.37 \%$ total protein) in larvae injected with AcMNPV expressing GFP+avidin was considerably higher than the level of GFP in larvae injected with either of the viruses. No avidin was detected in larvae injected with virus expressing GFP alone.

\section{DISCUSSION}

Expression of the insecticidal protein, avidin, by AcMNPV did not significantly reduce the time to kill $S$. litura larvae compared to the virus expressing only GFP. Further, it did 
not cause any significant difference in proportional mortality or growth rate of the $S$. litura larvae, although there was a trend towards higher proportional mortality in larvae injected with AcMNPV expressing avidin. The fact that there were no significant differences was unexpected as the expression of avidin in the insects was high $(>2 \%$ total protein; Airenne et al. 1997) and did not appear to rapidly kill those cells expressing the protein. In an earlier experiment (L.N. Gatehouse \& N.P. Markwick, unpubl. data), $S$. litura larvae were injected with each virus at full-rate, 0.1 and 0.5 dilutions. While significant differences in mortality and growth rate occurred when there was a 10-fold difference in dilution, there were no significant differences when virus dilutions were between 0.4 and 2 -fold. This suggests that a less than 2 -fold difference in titre in this experiment would not mask any difference in time to kill. In addition, the titre of virus recovered from cell culture was very similar for the two viruses (plus and minus avidin) suggesting that avidin expression does not affect viral replication.

Observation of GFP fluorescence indicated that the GFP accumulated rapidly, with total body fluorescence within $72 \mathrm{~h}$ of injection, and hence shows that the virus replicated quickly. Our results also indicate that, although avidin was expressed at higher levels than GFP, its expression did not change the level of GFP expressed. GFP on the p10 promotor is produced at a late stage in the viral cycle. Earlier experiments comparing budded wild-type AcMNPV with the GFP AcMNPV indicated that the expression of GFP itself was deleterious to the insects (L.N. Gatehouse \& N.P. Markwick, unpubl. data). However, we know of no published data supporting this. Our data show that any toxic effects of GFP delivered via a viral infection, as with avidin, are likely to be slow acting relative to the effects of the virus itself. Avidin on the polh promotor is produced at a similar late stage in the viral cycle to GFP on the p10 promotor and may not have accumulated in the insect tissues to high enough levels to adversely affect the insect before the insect was killed by the virus. Alternatively avidin delivered to the insect in this way may not have disrupted biotin metabolism as expected. While avidin expression on the strong late polh promotor was ineffective in reducing the time to kill of the virus, it is possible that using a strong early viral promotor would produce sufficient avidin early enough to have an effect.

\section{ACKNOWLEDGMENTS}

The insect larvae were supplied by Anne Barrington from the HortResearch Insectrearing Facility and statistical analyses were conducted by Anne Gunson from the HortResearch Biometrics team. This research was supported by FoRST contract C06X0001 and NSOF. We also gratefully acknowledge the support and advice of Dr Vernon Ward (University of Otago). The original avidin cDNA was supplied by Professor MS Kulomaa (Department of Biological and Environmental Science, University of Jyvaskyla, Finland).

\section{REFERENCES}

Airenne, K.J.; Oker-Blom, C.; Marjomaki, V.S.; Bayer, E.A.; Wilchek, M.; Kulomaa, M.S. 1997: Production of biologically active recombinant avidin in baculovirusinfected insect cells. Protein Expression and Purification 9: 100-108.

Armes, N.J.; Wightman, J.A.; Jadhav, D.R.; Roa, G.V.R. 1997: Status of insecticide resistance in Spodoptera litura in Andra Pradesh, India. Pesticide Sci. 50: 240-248.

Ayres, M.D.; Howard, S.C.; Kuzio, J.; Lopez-Ferber, M,; Possee, R.D. 1994: The complete DNA sequence of Autographica californica nuclear polyhedrosis virus. Virology 202: 586-605

Ayyanna, T.; Subbaratnam, G.V.; Dharmaraju, E. 1978: Pest complex on sunflower, Helianthus annus Lin in Andhra Pradesh. Indian J Entomol. 40: 353-356.

Bonning, B.C.; Hoover, K.; Booth, T.F.; Duffey, S.; Hammock, B.D. 1995: Arch. Insect Biochem. Physiol. 30: 177-194.

Bruins, B.G.; Scharloo, W; Thorig, G.E.W. 1991: The harmful effect of light on Drosophila is diet-dependant. Insect Biochem. 21: 535-539. 
Burgess, E.P.J.; Malone, L.A.; Christeller, J.T.; Lester, M.T.; Murray, C.; Philip, B.A.; Phung, M.M.; Tregidga, E.L. 2002: Avidin expressed in transgenic tobacco leaves confers resistance to two noctuid pests, Helicoverpa armigera and Spodoptera litura. Transgenic Res. 11: 185-198.

Chalfie, M.; Tu, Y.; Euskirchen, G.; Ward, W.W.; Prasher, D.C. 1994: Green fluorescent protein as a molecular marker for gene expression. Science 263: 802-805.

Chejanovsky, N.; Zilberberg, N.; Rivkin, H.; Zlotkin, E.; Gurevitz, M. 1995: Functional expression of an alpha anti-insect scorpion neurotoxin in insect cells and lepidopterous larvae. FEBS Letters 376:181-184.

Cory, J.S. 2000: Assessing the risks of releasing genetically modified virus insecticides: progress to date. Crop Prot. 19: 779-785.

Cory, J.S.; Hails, R.S.; Sait, S.M. 1997: Baculovirus Ecology. In: Miller, L.K. ed. The Baculoviruses. Plenum Press, New York. Pp. 301-339.

Fleming, T. H.; Harrington, D. P. 1984: Nonparametric estimation of the survival distribution in censored data. Comm. In Statistics 13: 2469-2486.

Gopalakrishnan, B.; Muthukrishnan, S.; Kramer, K.J. 1995: Baculovirus-mediated expression of a Manduca sexta chitinase gene: Properties of the recombinant protein. Insect Biochem. Molec. Biol. 25: 255-265.

Gope, M.L.; Keinänen, R.A.; Kristo, P.A.; Conneely, O.M.; Beattie, W.G.; Zarucki-Schultz, T.; O’Malley, B.W.; Kulomaa, M.S.1987: Molecular cloning of the chicken avidin cDNA. Nucleic Acids Res. 15: 3595-3606.

Hammock, B.D.; Bonning, B.C.; Possee, R.D.; Hanzlik, T.N.; Maeda, S. 1990: Expression and effects of the juvenile hormone esterase in a baculovirus vector. Nature 344: 458-461.

Harrington, D. P.; Fleming, T. R. 1982: A class of rank test procedures for censored survival data. Biometrika 69: 553-566.

Hayakawa, T.; Ei-ichi, S.; Mori, M.; Kaido, M.; Furusawa, I.; Miyata, S.; Matsumoto, T.; Hashimoto, Y; Granados, R. 2000: Enhancement of baculovirus infection in Spodoptera exigua (Lepidoptera: Noctuidae) larvae with Autographa californica nucleopolyhedrovirus or Nicotiana tabacum engineered with a granulovirus enhancing gene. Entomol. Zool. 35 (1): 163-170.

Hill, D. 1975: Agricultural Insect Pests of the Tropics and their Control. Cambridge University Press, London. 516 p.

Kramer, K.J.; Morgan, T.D.; Throne, J.E.; Dowell, F.E.; Bailey, M.; Howard, J.A. 2000: Transgenic avidin maize is resistant to storage insect pests. Nature Biotech 18: 670-674.

Li, S.Q.; Rahamann, H. 1997: Cotton Pest Management in China. I: Insect Pests. Zeitschrift fur Pflanzenkrankheiten und Pflanzenschultz 104: 611-621

Maeda, S. 1994: Expression of foreign genes in insect cells using baculovirus vectors. In: Maramorosch, K; McIntosh, A.H. ed. Insect Cell Biotechnology. CRC, Boca Raton, FL, USA. Pp. 1-31.

McManus, M.T.; Burgess, E.P.J. 1995: Effects of the soybean (Kunitz) trypsin inhibitor on growth and digestive proteases of larvae of Spodoptera litura. J. Insect Physiol. 41(9): 731-738.

Markwick, N.P.; Christeller, J.T.; Docherty, L.C.; Lilley, C.M. 2001: Insecticidal activity of avidin and streptavidin against four species of pest Lepidoptera. Entomol. Exp. Appl. 98: 59-66.

Martens, J.W.M.; Honee, G.; Zuidema, D.; van Lent, J.W.M.; Visser, B, et al. 1990: Insecticidal activity of a bacterial crystal protein expressed by a recombinant baculovirus in insect cells. Appl. Environ. Microbiol. 56: 2764-2770.

Miller, L.K. 1995: Genetically engineered insect virus biopesticides: present and future. $J$. Invertebr. Pathol. 65:211-216

Miller, L.K. 1997: The Baculoviruses. Plenum Press, New York. 447 p.

Morgan, T.D.; Oppert, B.; Czapal, T.H.; Kramer, K.J. 1993: Avidin and streptavidin as insecticidal and growth inhibiting dietary proteins. Entomol. Exp. Appl. 69: 97-108. 
Moscardi, F. 1999: Assessment of the Application of Baculoviruses for control of Lepidoptera. Ann. Rev. Entomol. 44: 257-89

Prasher, D.C.; Eckenrode, V.K.; Ward, W.W.; Prendergrast, F.G.; Cormier, M.J. 1992: Primary structure of the Aequorea victoria green-fluorescent protein. Gene 111: 229-233. Sahayaraj, K.; Paulraj, M.G. 1998: Screening the relative toxicity of some plant extracts to Spodoptera litura Fab. (Insecta: Lepidoptera: Noctuidae) of groundnut. Fresenius Environ. Bull. 7: 9-10; 557-560.

Statistical Sciences Inc. 1991. S-PLUS reference manual, version 3.0. Statistical Sciences, Seattle, WA. Version 3.4 Release 1 for Sun SPARC (1996)

Stewart, L.M.D.; Hirst, M.; Lopez Ferber, M.; Merryweather, A.T.; Cayley, P.J.; Possee, R.D. 1991: Construction of an improved baculovirus insecticide containing an insectspecific toxin gene. Nature 352: 85-88.

Treacy, M.F.; All, J.N.; Ghidiu, G.M. 1997: Effect of ecdysteroid UDP-glucosyltransferase gene deletion on efficacy of a baculovirus against Heliothis virescens and Trichoplusia ni (Lepidoptera: Noctuidae). J. Econ. Entomol. 90: 1207-14.

Zaz, G.M.; Kushwaha, K.S. 1984: Efficacy of Bacillus cereus Frankland and Frankland against different instars of Spodoptera litura (Fabricius) fed on treated cauliflower leaves. J. Entomol. Res. 8: 216-219. 